\title{
STUDIES IN AUSTRALIAN STIPA (POACEAE)
}

\author{
J. EVERETT AND S.W.L. JACOBS
}

\section{ABSTRACT}

(Accepted for publication 14.2.1983)

\begin{abstract}
Everett, J. and Jacobs, S.W.L. (Royal Botanic Gardens, Sydney, Australia 2000). 1983. Studies in Australian Stipa (Poaceae). Telopea 2(4): 391-400, fig. 1.-The Stipa nervosa-S. rudis complex is examined with the help of a phenetic taxonomic analysis and considered to consist of one species, $S$. rudis Spreng., with three subspecies, S. rudis subsp. rudis, $S$. rudis subsp. nervosa (Vickery) J. Everett \& $S$. W.L. Jacobs comb. et stat. nov. and $S$. rudis subsp. australis $J$. Everett \& S.W.L. Jacobs subsp. nov. Three new species are described, all related to $S$. eremophila: S. vickeryana $J$. Everett \& S.W.L. Jacobs, S. nullanulla J. Everett \& S.W.L. Jacobs, and S. metatoris J. Everett \& S.W.L. Jacobs.
\end{abstract}

\section{INTRODUCTION}

While continuing a revision of the genus Stipa (Poaceae) in Australia commenced by the late Dr Joyce Vickery we have dealt with some taxa not treated by her notes. We have also made decisions regarding other taxa in which we slightly differ from her notes.

Here we present a treatment of the Stipa rudis/S. nervosa complex on which Dr Vickery had reached some conclusions but on receipt of additional specimens had clearly intended to work further.

We also describe three new species not noted by Dr Vickery, one of which we are naming in her honour.

Vickery (1951) originally described Stipa nervosa with two varieties, var. nervosa and var. neutralis. When she discovered that the type of $S$. rudis Spreng. (1827) corresponded with the variety neutralis she suggested that the two taxa be known as $S$. nervosa and $S$. rudis respectively (as in Jacobs and Pickard, 1981). Tasmanian and east-coast material from Victoria originally identified as $S$. nervosa var. neutralis did not fit her concept of this taxon and was put aside. Townrow (1978), who provided much of the Tasmanian material, however, recognised the two varieties of $S$. nervosa, of which only the variety neutralis was represented in Tasmania. Townrow apparently regarded $S$. rudis as a quite separate taxon (pers. comm. to Dr Vickery).

As there was some confusion and difference of opinion regarding the status of these taxa and their nomenclature, we decided to undertake more detailed analyses than appear to be required for the rest of the genus.

\section{METHODS}

A preliminary survey of Stipa nervosa, $S$. rudis and the closely related plants of doubtful affinity from Victoria and Tasmania indicated a possible discontinuity in awn lengths between the Tasmanian specimens and the others. This discontinuity appeared to be correlated with differences in glume texture and in overall spikelet dimensions.

A geographically representative sample of 43 specimens was taken, covering the morphological range, and observations of 15 characters were made on each as follows: 
1. Ligule length, $\mathrm{mm}$

2. Ligule shape; obtuse/truncate/laciniate

3. Panicle length, $\mathrm{cm}$

4. Upper glume length, $\mathrm{mm}$

5. Upper glume breadth at the centre, $\mathrm{mm}$

6. Upper glume breadth relative to length

7. Upper glume tip shape; truncate/acute/erose

8. Floret length, mm (including callus, excluding awn)

9. Palea length relative to lemma length

10. Callus length, mm (after removal of its hair tuft)

11. Callus length relative to lemma length

12. Awn length, $\mathrm{mm}$

13. Proximal column-segment length, $\mathrm{mm}$ (from the apex of the lemma to the first bend)

14. Column width, mm (halfway along the proximal column-segment)

15. Column indumentum length, $\mathrm{mm}$

Ligule characters were taken from the culm leaf directly below the panicle leaf. Spikelets were taken from the second and third most distal nodes of the panicle.

A set of twelve spikelet characters (characters 4-15) was recorded from each of two spikelets per specimen. Each set shared three vegetative and panicle characters with the other set taken from the same specimen. As there were 43 specimens used in the analysis, there were 86 sets of information.

The data were processed with the help of a computer and a phenetic taxonomic analysis, MULCLAS (Lance and Williams, 1967), a polythetic agglomerative program, available in the CSIRO TAXON (1977) package. The distance measure used was the Euclidean Squared Metric (CSIRO TAXON, 1977) and the fusion strategy that of Burr (1968).

Only quantitative data were used in the computer analysis (13 characters), reserving the two qualitative characters of ligule and glume tip shape for later comparisons. The computer analysis combined similar sets and then progressively fused these in a sequence from which a dendrogram was constructed. Additionally a measure of discrimination (Cramer value) was given for each character (Lance \& Williams, 1977).

\section{RESULTS}

\section{The Dendogram (Fig. 1)}

By truncating the dendrogram at the lowest level of information that maintains the pairs of data from a single specimen in the same group, two groups are produced (shown by line A). These groups correspond to (I) $S$. rudis and (II) the allied groups of plants from Victoria and Tasmania which we are designating as $S$. rudis subsp. australis. However, if one accepts one split pair at a lower level (shown by line B), three groups are obtained (group I being split), corresponding to 1 . S. rudis subsp. nervosa, 2. $S$. rudis subsp. rudis and 3 . S. rudis subsp. australis.

The type of $S$. nervosa var. nervosa is included in group 1 and is easily distinguishable from the type of $S$. nervosa var. neutralis which is included in group 2 . 


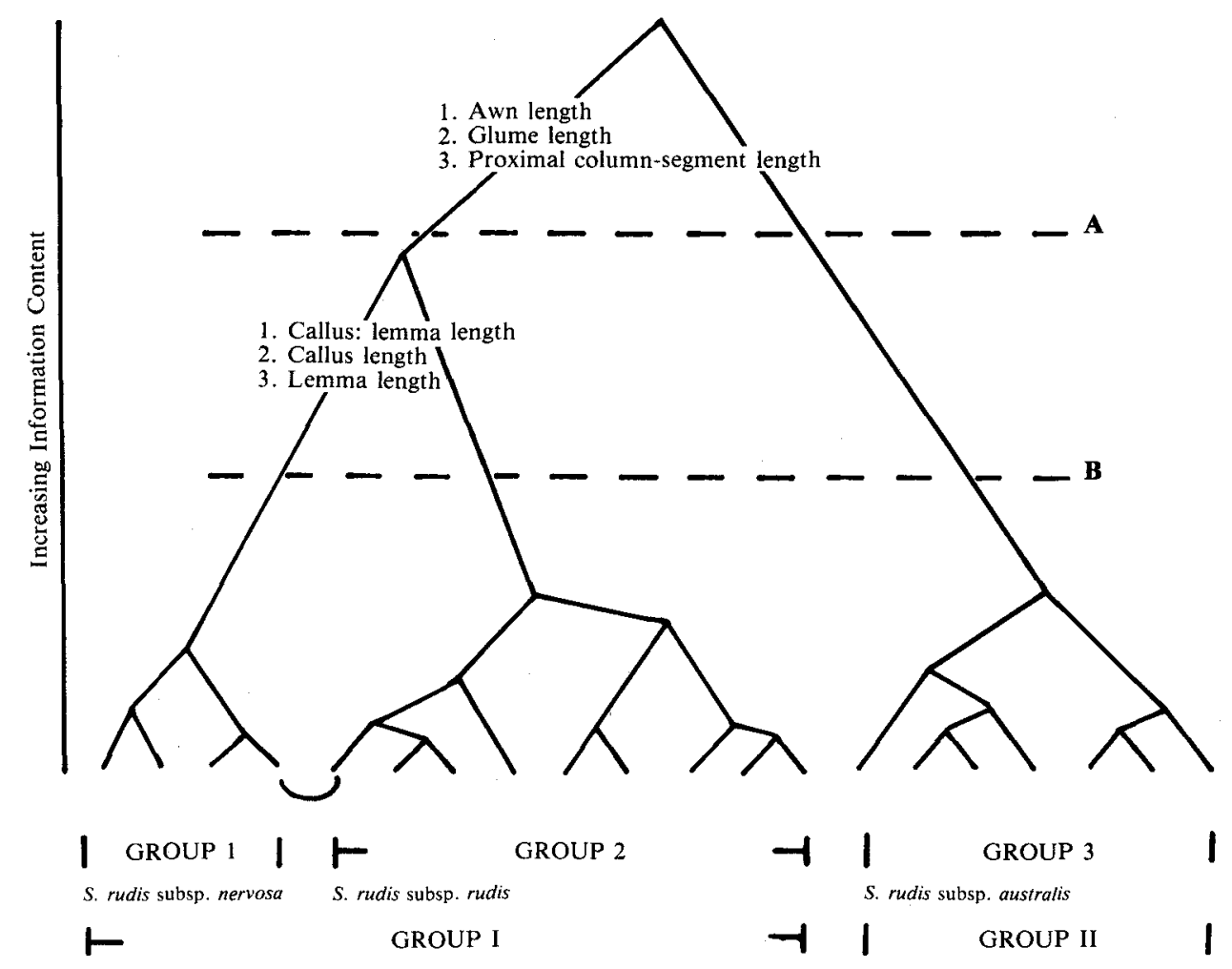

Fig. 1: Analysis of 43 specimens of S. rudis: Dendrogram summarizing the results of MULCLAS analysis of 86 sets of 13 characters. Also shown are the most useful characters distinguishing the two levels of division into:

line A, S. rudis subsp. rudis together with subsp. nervosa, and S. rudis subsp. australis;

line B, $S$. rudis subsp. rudis and $S$. rudis subsp. nervosa allowing the two sets of measurements for one specimen to bridge the borders of groups $1 \& 2$.

\section{The Characters}

For each division the three most useful characters for distinguishing the resulting groups (i.e. those with the highest Cramer values) are shown in Fig. 1.

These groupings based on quantitative data are supported by the upper glume tip shapes partly observed by Dr Vickery: $S$. rudis subsp. nervosa with narrowly truncate glume tips, $S$. rudis subsp. rudis either with narrowly truncate glume tips, or more commonly with the upper glume broadly ovate, and $S$. rudis subsp. australis with both glumes broadly obtuse. The narrowly truncate tips are firm and the broadly obtuse tips are membranous, and often erose. Ligule shape and length show no pattern consistent with these groupings.

\section{Reasons for recognition of taxa at subspecific rank}

When the entire collection is sorted using the most useful discriminating characters (listed on Fig. 1) the groups obtained from the dendrogram reappear except that some few intermediates occur between groups 2 and 3 . To varying degrees these intermediates have the awn and column length of $S$. rudis subsp. rudis but the broad and erose glume tips of $S$. rudis subsp. australis, a character hard to ignore because the appearance is so different from the narrow-truncate, firm tips of $S$. rudis subsp. nervosa. Nevertheless these "intermediates" are closer in other respects to $S$. rudis subsp. rudis and are treated by us as subsp. rudis. The intermediates are found on 
the east coast of Victoria, the area on the mainland where $S$. rudis subsp. australis (which is predominantly Tasmanian) has been collected.

There is a less definite distinction between subsp. rudis and subsp. nervosa, with a number of specimens sharing features from both subspecies and making their identification with one or the other taxon somewhat arbitrary.

Again, because of these intermediates, we feel that the rank of subspecies is the most appropriate for these groups.

\section{DESCRIPTIONS}

The following description of $S$. rudis covers all three subspecies; the subspecies descriptions give those characters that vary between the subspecies.

Stipa rudis Spreng., Syst. Veg. 4, Cur. Post.: 31 (1827).

HolotyPe: Australia: 'Nov. Holl. (St. pubescens Nees in Sieb. agrost. n. 66)' [from protologue] (?P-not seen). IsotyPES: Agrostotheca No. 66 (MEL 59980, 59982).

SyNONYM: Stipa nervosa Vickery in Contr. New South Wales Natl. Herb. 1: 337 (1951). HoLOTYPE: Australia-New South Wales: Epping, W.F. Blakely NSW 8491, 10.1913 (NSW). IsOTYPE: K - not seen.

Caespitose perennial up to $1.2 \mathrm{~m}$ high with conspicuously extravaginal shoots often from a short rhizome. Culms usually geniculate near the base, slightly compressible, terete, (1-) 2-4 mm wide near the base, slightly ribbed, mainly glabrous or finely scaberulous, but finely pubescent for varying lengths below the nodes; nodes $2-4$, exserted, up to $50 \%$ broader than adjacent internodes, densely pubescent with short, appressed to slightly spreading hairs. Leaf sheaths inflated and falling loose from the culms, slightly ribbed, glabrous to finely and sparsely pubescent, more densely pubescent on the margins just below the orifice, hirsute around the collar; inner margin glabrous; outer margin ciliate just below the orifice of lower sheaths; uppermost sheaths glabrous; cataphylls glabrous, pubescent or shortly villous. Ligule coriaceous, $0.5-2 \mathrm{~mm}$ long, ovate to ovate-truncate, and slightly laciniate, long- to short-ciliate, abaxial surface pubescent; auricles slightly thickened, with tufts of long to short spreading hairs. Leaf blades up to $40 \mathrm{~cm}$ long, $2-5 \mathrm{~mm}$ wide near the base, erect, usually inrolled, the basal leaves more tightly rolled; abaxial surface scarcely ribbed or smooth, very densely to sparsely scabrous with minute, rigid tubercles or hairs, or almost glabrous; adaxial surface ribbed, densely pubescent or hirsute to sparsely scabrous with minute short hairs; margins with rigid tubercles or hairs similar to those of the abaxial surface or glabrous. Panicle up to $50 \mathrm{~cm}$ long, $1.5-5 \mathrm{~cm}$ wide (excluding awns), exserted or the base concealed, loosely contracted to spreading with distant fascicles of few branches; axis terete, almost glabrous at the base to scabrous upwards; branches up to $15 \mathrm{~cm}$ long, terete, scabrous with short to long hairs; pedicels up to $15 \mathrm{~mm}$ long, angular, scabrous. Spikelets $8-15 \mathrm{~mm}$ long (excluding awn), gaping. Glumes unequal to subequal, linear to broadly oblong, with nerves heavily overlaid with sclerenchyma and associated with chlorenchyma bands, pale green to yellow or purple-tinged, glabrous with minute scabrous hairs over the nerves and the margins often ciliate, or pubescent overall; lower glume 8-15 mm long, the lower $85-90 \%$ 3-nerved, the tip narrowly truncate and firm or broadly obtuse, membranous and erose; upper glume 7-14.5 mm long, the lower 75-90\% 3-nerved or 4 to 5 nerves present in the lower $25-75 \%$, the tip truncate and firm to membranous or broadly obtuse, membranous and erose. Floret linear, lanceolate to fusiform, 5-11.5 mm long (including callus). Lemma brown to purple-brown at maturity, granular at the base, tuberculate upwards, with antrorse hooks most pronounced at maturity, with sparse fulvous to white hairs at the base, thinning to usually glabrous at the apex; coma obscure, of few hairs up to $1 \mathrm{~mm}$ long, or absent; lobe, $1,0.05-0.25 \mathrm{~mm}$ long and obtuse, or absent. Callus 0.8-3.2 m long, gently curved with fulvous to white hairs, darker than those of the lemma. Awn 20-90 mm long, 0.15-0.4 mm wide near the base, gently to strongly twice bent; column $8-45 \mathrm{~mm}$ long, $4.5-30 \mathrm{~mm}$ to the first bend, scabrous to softly pubescent with hairs $0.05-0.3 \mathrm{~mm}$ long; bristle scabrous. 
Palea $0.5-1.2 \mathrm{~mm}$ shorter than the lemma, acute to broadly acute, granular down the centre with hairs similar to those of the lemma, or almost glabrous; margins firm, smooth and glabrous. Lodicules 2-3, membranous; 2 abaxial 0.8-1.7 mm long, oblong to spathulate; paleal, when present, acute, about $1 \mathrm{~mm}$ long. Anthers $2.0-4.0 \mathrm{~mm}$ long, lightly penicillate. Caryopsis 3-6 mm long; embryo 20-25\% the length; hilum $70-80 \%$ the length.

\section{KEY TO SUBSPECIES}

1. Awn $60-90 \mathrm{~mm}$ long, column $32-45 \mathrm{~mm}$ long, both glumes broadly obtuse with $1-2 \mathrm{~mm}$ of delicately membranous tip, upper glume $11-14.5 \mathrm{~mm}$ long $\ldots \ldots \ldots \ldots$. rudis subsp. australis

1* Awn usually less than $60 \mathrm{~mm}$ long, occasionally up to $65 \mathrm{~mm}$ long, column usually less than $25 \mathrm{~mm}$ long, occasionally up to $30 \mathrm{~mm}$ long; glumes firm to the tip, or, especially the upper, membranous at the very tip, upper glume $7-12.5 \mathrm{~mm}$ long $\ldots \ldots \ldots \ldots \ldots \ldots \ldots \ldots \ldots \ldots$

2. Callus $1.5-2.5 \mathrm{~mm}$ long, usually more than $20 \%$ the length of the floret (excluding awn); column 20-25 mm long; lower glume narrowly truncate and firm or membranous at the tip, upper glume membranous at the tip, $9-12.5 \mathrm{~mm}$ long $\ldots \ldots \ldots \ldots \ldots \ldots$. rudis subsp. rudis

2. Callus 0.8-1.7 mm long, usually less than $20 \%$ the length of the floret (excluding awn); column less than $20 \mathrm{~mm}$ long; glumes narrowly truncate, firm at the tip, the upper glume $7-10 \mathrm{~mm}$ long

S. rudis subsp. nervosa

\section{Stipa rudis subsp. rudis}

SYNONYM: S. nervosa var. neutralis Vickery in Contr. New South Wales Natl. Herb. 1: 335 (1951). HolotYPE: New South Wales: Katoomba, S.T. Blake NSW 13915, 22.1.1939 (NSW).

Nodes up to $50 \%$ broader than internodes. Cataphylls glabrous or pubescent. Leaf blades up to $40 \mathrm{~cm}$ long; adaxial surface pubescent to sparsely scabrous with minute short hairs. Panicle up to $40 \mathrm{~cm}$ long, $1.5-4 \mathrm{~cm}$ wide (excluding awns); pedicels up to $10 \mathrm{~mm}$ long. Spikelets $10-15 \mathrm{~mm}$ long (excluding awn). Glumes unequal, glabrous with minute scabrous hairs over the nerves, the margins often ciliate; lower glume 10-15 mm long, the lower 90\% 3-nerved, the tip narrowly truncate and firm or membranous; upper glume 9-12.5 mm long, the lower $90 \% 3$-nerved, 4-5 nerved in the lower $25-50 \%$, the tip obtuse and membranous. Floret $7.2-10 \mathrm{~mm}$ long (including callus). Coma absent. Callus 1.5-2.5 mm long. Awn (35-) 40-60 (-65) mm long, 0.15-0.4 $\mathrm{mm}$ wide, gently to strongly twice bent; column $20-25 \mathrm{~mm}$ long, $10-20 \mathrm{~mm}$ to the first bend. Caryopsis $3-5.5 \mathrm{~mm}$ long.

\section{Selected SPecimens Examined:}

QueEnSLAND: Moreton: Moggill nr. Brisbane, White 7590, 3.4.1931 (BRI). Darling Downs: Wyberba, Blake 4638A, 23.1.1933 (NSW).

New SouTH WALES: Northern Tablelands: Yooroonah, McKie NSW 8584, 12.1.1940 (NSW); Glen Elgin, Paltridge 211, 3.12.1931 (CANB). Central Coast: Pennant Hills, Vickery NSW 6351, 6.12.1953; $4.8 \mathrm{~km}$ S. of Picton, Everett 26 \& Jacobs, 12.11 .1980 (NSW). Central Tablelands: Wentworth Falls, Henderson f 55, 3.1945 (NSW); Blackheath, Constable NSW 16356, 22.1.1948 (NSW); Katoomba, Blake NSW 13915, 22.1.1939 (NSW). Southern Tablelands: Crookwell, Hewitt NSW 8566, 9.2.1948 (NSW). South Coast: $5 \mathrm{~km}$ NE. of N.S.W./Vic. border on Princes Hwy, Everett 442 \& Jacobs, 22.10.1981 (NSW); Lyons Road, Currowan State Forest, Pullen 3968, 6.12.1963 (CANB).

VICTORIA: Region S: Warburton, Blake 7219, 19.1.1935 (BRI, NSW). Region Z: c. 5 miles [8 km] direct NE. of Mallacoota P.O., Z 35, Beauglehole 32495 \& Finck, 16.12.1969 (NSW).

Specimens with some characteristics of $\mathrm{S}$. rudis subsp. australis:

Victoria: Region N: Near Lilydale, Blake 7211, 19.1.1935 (NSW). Region T: Traralgon, Meebold $21580,12.1936$ (NSW). Region W: 16 km N. of Swan Reach, Everett 414 \& Jacobs, 21.10 .1981 (NSW). Region Z: Lind National Park, Z 30, Beauglehole 32392 and Finck, 14.12.1969 (NSW). 


\section{nov. \\ Stipa rudis subsp. nervosa (Vickery) J. Everett \& S.W.L. Jacobs, comb. et stat.}

BASIONYM: $S$. nervosa var. nervosa Vickery in Contr. New South Wales Natl. Herb. 1: 335 (1951). HolotYPE: New South Wales: Epping, W.F. Blakely NSW 8491, 10.1913 (NSW). IsOTYPE: K - not seen.

Nodes up to $25 \%$ broader than internodes. Cataphylls pubescent, shortly villous or glabrous. Ligule $0.5-1.5 \mathrm{~mm}$ long. Leaf blades up to $40 \mathrm{~cm}$ long; adaxial surface pubescent to sparsely scabrous with minute short hairs. Panicle up to $50 \mathrm{~cm}$ long, $1.5-3 \mathrm{~cm}$ wide (excluding awns); pedicels up to $10 \mathrm{~mm}$ long. Spikelets $8-12 \mathrm{~mm}$ long (excluding awn). Glumes unequal, glabrous with minute scabrous hairs over the nerves, the margins often ciliate; lower glume 8-12 mm long, the lower 90\% 3-nerved, the tip narrowly truncate and firm; upper glume $7-10 \mathrm{~mm}$ long, the lower $90 \% 3$-nerved or 4-5-nerved in the lower 50-60\%, the tip truncate and firm. Floret 5-7.5 (-8.5) mm long (including callus), with white hairs. Coma usually present but obscure, of few hairs up to $1 \mathrm{~mm}$ long. Callus 0.8-1.7 mm long. Awn 20-45 mm long, 0.15-0.25 mm wide, gently twice bent; column (8-) $11-18(-20) \mathrm{mm}$ long, $4.5-11 \mathrm{~mm}$ to the first bend. Caryopsis 3-4.5 mm long.

\section{Selected Specimens Examined:}

QUEENSLAND: Darling Downs: Wallangarra, Hilton NSW 116191, 22.12.1944.

New SOUTH WALES: Northern Tablelands: Moredun Creek Dam, McKie NSW 8494, 30.12.1947; SW. of Guyra, Youman NSW 116200, 24.12.1931. Central Tablelands: Katoomba, Blake 13932, 23.1.1939 (NSW); 15 miles [24 km] ENE. of Capertee, Vickery NSW 116204, 6.1.1975. Central Coast: Epping, Blakely NSW 8491, 10.1913 (Type of S. nervosa); Nepean River, c. 4 miles [6 km] S. of Wallacia, Salasoo 2678, 1.12.1963. Southern Tablelands: Yalwal, Rodway NSW 116189, 2.1.1933; Conder Creek, A.C.T., Gauba NSW 116187, 11.1.1959. South Coast: Milton, Cambage NSW 8499, 23.12.1908.

Victoria: Region R: Little Paradise Falls, \pm 27 miles [43 km] SW. of Myrtleford, Beauglehole 43767 \& Cameron, 5.12.1973 (NSW). Region X: Sale, Vickery NSW 8530, 26.1.1935.

\section{Stipa rudis subsp. australis J. Everett \& S.W.L. Jacobs, subsp. nov.}

A subspecie typica arista longiore $60-90 \mathrm{~mm}$ longa, columna $32-45 \mathrm{~mm}$ longa, glumis plerumque latioribus apice membranaceo, differt.

HolotyPE: TASMANIA: Risdon. Robust coarse grass, spreading panicle. Abundant. J. Vickery NSW 108620, 18.1.1949 (NSW).

Cataphylls glabrous or pubescent. Nodes up to $40 \%$ broader than internodes. Ligule $0.5-2.0 \mathrm{~mm}$ long. Leaf blades up to $20 \mathrm{~cm}$ long; adaxial surface densely pubescent or hirsute. Panicle up to $40 \mathrm{~cm}$ long, $4-5 \mathrm{~cm}$ wide (excluding awns); pedicels up to $15 \mathrm{~mm}$ long. Spikelets $12-15 \mathrm{~mm}$ long (excluding awn). Glumes subequal, glabrous with minute scabrous hairs over the nerves, the margins ciliate to pubescent overall; lower glume $12-15 \mathrm{~mm}$ long, the lower $85 \%$ 3-nerved, the tip broadly obtuse, membranous and erose; upper glume 11-14.5 mm long, the lower 75-90\% 3-nerved, 4-5-nerved in the lower $50-75 \%$, the tip broadly obtuse, membranous and erose. Floret 8.6-11.5 mm long (including callus). Coma absent. Lobes absent. Callus 2.0-3.2 mm long. Awn 60-90 mm long, 0.3-0.4 mm wide, gently to strongly twice bent; column 32-45 mm long, 20-30 $\mathrm{mm}$ to the first bend. Caryopsis about $6 \mathrm{~mm}$ long.

\section{Selected SPecimens EXAmined:}

TASMANIA: 2 miles [3 km] E. of Mathinna, Townrow 197, 2.1968 (Townrow); Risdon, Vickery NSW 108620. 18.1.1949; Kingston, junction of main road with Lesleyvale road, Townrow 165, 1.1968 (Townrow); 1 mile [1.5 km] W. of Dunalley Bridge, Townrow 103, 1.1967 (Townrow); Mt Wellington, Martin NSW 108622, 3.1933; Mathinna, Phillips CBG 001268, 29.1.1962 (NSW, CBG-not seen); Evandale, beside South Esk Bridge, Townrow 114, 19.12.1967 (University of Tasmania); c. 10 miles [16 km] W. of Copping, Vickery NSW II7311, 15.1.1949; Launceston, Cheel NSW 108621, $1.1928 ; 1 / 2$ mile [1 km] E. of O'Connors Peak/Campbelltown road junction, Townrow 124, 12.1967 (Townrow).

VICTORIA: Region W: $1 \mathrm{~km} \mathrm{NE}$. of Metung, Everett 422 \& Jacobs, 21.10 .1981 (NSW); $3 \mathrm{~km} \mathrm{NE.}$ of Metung, Everett 428 \& Jacobs, 21.10.1981 (NSW). Region Z: Buchan, Verdon 493, 21.11.1970 (CBG); c. 2.5 miles [4 km] direct W. of Genoa P.O., Tobins Creek, Beauglehole 32767, 24.12.1968 (NSW). 


\section{NEW SPECIES IN STIPA}

The following three species were separated in the course of the revision. None of these taxa was covered by Dr Vickery's notes. A key is provided to discriminate them from related species.

\section{Key to the new species and related taxa}

1. Lemma glabrous to very sparsely pubescent; ligule of upper leaves more than $3 \mathrm{~mm}$ long $\ldots .2$

1.* Lemma densely pubescent; ligule of upper leaves less than $2 \mathrm{~mm}$ long $\ldots \ldots \ldots \ldots$

2. Mature lemma white or very pale yellow; coma absent $\ldots \ldots \ldots \ldots \ldots \ldots \ldots \ldots \ldots$

2.* Mature lemma dark brown; coma of two tufts of hair $1-1.5 \mathrm{~mm}$ long $\ldots \ldots \ldots \ldots$

3. Leaf sheaths covered with transparent, flattened and flexuose hairs ........ S. macalpinei

3.* Leaf sheaths glabrous or minutely scaberulous $\ldots \ldots \ldots \ldots \ldots \ldots \ldots \ldots \ldots$ compressa

4. Awn $5-7 \mathrm{~cm}$ long; spikelet $9-11 \mathrm{~mm}$ long (excluding awn) ............ nullanulla

4.* Awn (8-) 9-12.5 cm long; spikelet 14-18 mm long (excluding awn) ........ S. vickeryana

5. Coma of sparse stiff hairs less than $1 \mathrm{~mm}$ long $\ldots \ldots \ldots \ldots \ldots \ldots \ldots \ldots$ eremophila

5.* Coma of dense weak hairs more than $2 \mathrm{~mm}$ long $\ldots \ldots \ldots \ldots \ldots \ldots \ldots$ metatoris

\section{Stipa vickeryana $J$. Everett $\&$ S.W.L. Jacobs, sp. nov.}

A $S$. eremophila lemmate glabro pro parte maxima, orificio lanato, ligula laciniata multo longioreque, differt.

Holotype: South Australia: Ifould Lake, Nullarbor Plain Series R502 Barton $512174,30^{\circ} 55^{\prime} \mathrm{S}$, $132^{\circ} 05^{\prime} \mathrm{E}$. Common grass. Forming dense clumps. Heads open, spreading. R.J. Chinnock 2729, 2.x.1975 (AD).

Caespitose annual or perennial to $45 \mathrm{~cm}$ high. Culms (1.5-) 2-2.5 mm wide near the base, terete to slightly flattened, ribbed, glabrous; nodes 1-2, glabrous. Leaf sheaths loose around the culms, glabrous except for the shortly pubescent bases of lowermost sheaths; outer margin fringed with long, woolly cilia; inner margin not ciliate. Ligule 3.5-8 (-13) mm long, laciniate, densely ciliate with long woolly hairs especially on those of the lower sheaths. Leaf blades to $18 \mathrm{~cm}$ long, $1.5-4 \mathrm{~mm}$ wide, often folded; abaxial surface unribbed, glabrous except for the very sparsely scabrous long-acute tip; adaxial surface strongly ribbed, the ribs covered with short \pm antrorse hairs. Panicle $9-20 \mathrm{~cm}$ long, slightly spreading, the base enclosed by the sheath. Spikelets scarcely gaping at maturity, widely gaping after floret disarticulation, 14-18 $\mathrm{mm}$ long (excluding awn). Glumes unequal, firm at the base, hyaline at the fine acuminate tip, the lower $75 \%$ 3-nerved, scaberulous on the nerves, glabrous between the nerves or minutely pubescent, especially at the tip; the lower $14-18 \mathrm{~mm}$ long, 3-nerved; the upper 9-14 $\mathrm{mm}$ long, 5-nerved at the base. Floret fusiform to turbinate, 6-7 mm long (including callus). Lemma deep brown at maturity, smooth except for an antrorsely scabrous neck, glabrous to very sparsely clothed with coppery hairs, denser along the margins; coma sparse, 1-1.5 mm long in two tufts. Callus straight, 2.5-3 mm long, with a tuft of coppery hairs. Awn relatively slender for its length, c. $0.3 \mathrm{~mm}$ wide near the base, (80-) $90-125 \mathrm{~mm}$ long, \pm straight to gently twice bent or sinuate; column $26-32 \mathrm{~mm}$ long, $15-18 \mathrm{~mm}$ to the first bend, densely pubescent with antrorse hairs $0.2-0.3 \mathrm{~mm}$ long; bristle antrorsely scabrous. Palea obtuse, subequal to the lemma, with sparse coppery hairs along the midline Lodicules 3, membranous, spathulate, the two abaxial about $1 \mathrm{~mm}$ long, the paleal much smaller. Anthers not observed. Caryopsis not observed.

SPECIMENS EXAMINED: SOUTh AuSTRAliA: Nullarbor: Ifould Lake. Series R502 Barton 512174, $30^{\circ} 55^{\prime} \mathrm{S}, 132^{\circ} 05^{\prime} \mathrm{E}$, Chinnock 2729, 2.10.1975 (AD, NSW); Lake Ifould Crossing, B. Copley 2644, 28.7.1969 
(AD); W. of Yarle Lakes, Bowen 312, 9.1956(K). WeStern AuSTRAlia: Coolgardie: Norseman, Andrews, 10.1903 (PERTH).

The specific epithet is in honour of the late Dr Joyce Vickery.

Differs from S. eremophila in having only few scattered hairs on the lemma (densely hairy in S. eremophila), in its long-hairy orifices, (glabrous or sparsely hairy in $S$. eremophila) and longer (usually less than $1.5 \mathrm{~mm}$ in $S$. eremophila) laciniate ligule. $S$. vickeryana vegetatively resembles $S$. macalpinei but differs in its less hairy, broader and darker-coloured mature lemma. Additionally, on the sheaths $S$. macalpinei has characteristic broad, curled, glistening-translucent hairs, quite different from the narrow, crinkled, more opaque hairs on those of $S$. vickeryana.

$S$. vickeryana differs from $S$. nullanulla in having coarser, usually folded leaves (rolled in S. nullanulla), a less open inflorescence and longer lemma and awn.

\section{Stipa nullanulla J. Everett \& S.W.L. Jacobs, sp. nov.}

A S. eremophila lemmate pro parte maxima glabro brevioreque, arista tenuiore ligula longiora longiciliataque, differt.

HOLOTYPE: NEw SOUTH WALES: "Nulla Nulla", $2 \mathrm{~km}$ south of gate at northern end of Bluff paddock. Saltbush, mallee, Myoporum sp., Everett 133 \& Jacobs, 25.11.1980 (NSW). IsoTYPE: AD.

Small caespitose perennial $40-50 \mathrm{~cm}$ high with a loosely contracted rootstock. Culms slender, 1-2 mm wide near the base, terete, smooth, mostly glabrous but retrorsely pubescent just below the nodes; nodes 2 , glabrous, rarely exserted. Leaf sheaths broad, loose around the culm, glabrous or the lower sheaths scaberulous to pubescent between the nerves; outer margin densely woolly especially on lower sheaths; inner margin sparsely woolly. Ligule $1-5(-10) \mathrm{mm}$ long, membranous, laciniate, with woolly cilia to $9 \mathrm{~mm}$ long on tips and back. Leaf blades linear, usually rolled, rigid, up to $30 \mathrm{~cm}$ long and $2-3 \mathrm{~mm}$ wide; abaxial surface unribbed, very finely scaberulous; adaxial surface strongly ribbed, the ribs covered with short antrorse hairs; margins strongly scabrous. Panicle short, $13-19 \mathrm{~cm}$ long, delicate and spreading, axis very sparsely scabrous with distant fascicles of unequal compound branches; branches 4-60 mm long, scabrous, scaberulous or shortly pubescent; pedicels similar to the branches, 3-15 mm long. Spikelets narrowly gaping at maturity, widely gaping after floret disarticulation, rather small, 9-11 mm long (excluding awn). Glumes subequal, green at the base, chartaceous at the tip, 3 nerves visible for much of the length, acute to shortly acuminate; the lower 9-11 mm long, 3-nerved; the upper 8-10 mm long, 5-nerved at the base. Floret cylindrical to narrow-fusiform, 5-6 $\mathrm{mm}$ long (including callus). Lemma smooth with an antrorsely scabrous neck, glabrous to very sparsely covered with slightly spreading yellow hairs, at maturity tightly convolute, dark brown with the 5 nerves pale yellow, visible externally; coma sparse, 1-1.5 mm long in two tufts. Callus straight, 2.0-2.7 mm long, with appressed yellow-brown hairs. Awn slender, $0.25 \mathrm{~mm}$ wide near the base, $5-7 \mathrm{~cm}$ long, gently twice bent; column $1.8-2.5$ $\mathrm{cm}$ long, $1-1.5 \mathrm{~cm}$ to the first bend, shortly pubescent with antrorse hairs to $0.2 \mathrm{~mm}$ long; bristle strongly antrorsely scabrous. Palea acute to obtuse, about as long as the lemma, glabrous or with a sparse apical tuft. Lodicules 3, membranous, oblong; 2 abaxial about $1 \mathrm{~mm}$ long; paleal minute or rarely equal in size to the palea. Caryopsis 2.7-3.0 mm long, embryo $25-35 \%$ the length, hilum $65-75 \%$ the length.

SPECIMEns Examined: New South Wales: South Far Western Plains: "Nulla Nulla" unit 37, Stanley 1784, 3.12.1975 (NSW); "Nulla Nulla", Everett 130,132, 133, 138 \& Jacobs, 25.11.1980 (NSW).

The specific epithet is derived from the name of the property to which this species now appears to be confined. Aboriginal in origin, this epithet is indeclinable in Latin.

Differs from $S$. eremophila in the mostly glabrous and shorter lemma (densely hairy, 6-9.5 $\mathrm{mm}$ in $S$. eremophila), in the finer awns, the longer, long-ciliate ligules (to $1.5 \mathrm{~mm}$, short-ciliate in $S$. eremophila). See $S$. vickeryana for a comparison with that species. 
Apparently restricted to gypsaceous rises. Palatable to sheep and rabbits and now confined to the shelter of shrubs and other protected places.

\section{Stipa metatoris J. Everett \& S.W.L. Jacobs, sp. nov.}

A $S$. eremophila coma longiore $2.5-3.5 \mathrm{~mm}$ longa, pilis lemmatis longioribus pallidioribusque, arista plerumque breviore tenuioreque, differt.

Holotype: New South Wales: Kyalite State Forest, $34^{\circ} 58^{\prime} \mathrm{S}, 148^{\circ} 32^{\prime} \mathrm{E}$. Sandridge with Dodonaea and Callitris, J. Everett 341 \& S.W.L. Jacobs, 16.10.1981 (NSW).

Caespitose perennial to about $1 \mathrm{~m}$ high, with a basal tuft of leaves at least half the total height. Culms erect or geniculate, $1.5-2.5 \mathrm{~mm}$ wide near the base, terete, not compressible, scarcely ribbed, densely pubescent to pubescent to puberulous or glabrous upwards; nodes $2-3$, densely pubescent, exserted, up to $50 \%$ wider than adjacent internodes. Leaf sheaths tight around the culms, loose with age, 4-6 mm wide (the uppermost inflated and up to $8 \mathrm{~mm}$ wide), densely pubescent to hirsute, or glabrous upwards; inner margin glabrous; outer margin densely ciliate with long hairs; cataphylls ciliate on both margins. Ligule thinly coriaceous $1.0-2.2 \mathrm{~mm}$ long, broadly acute, obtuse to truncate, but always laciniate, densely ciliate, abaxial surface villous; auricles densely ciliate with long, fine, straight hair tufts. Leaf blades mostly tightly inrolled, 2-4 mm wide, up to $40 \mathrm{~cm}$ long; abaxial surface scarcely ribbed, scaberulous and sparsely to densely pubescent, to almost glabrous; adaxial surface strongly ribbed, densely pubescent; margins scabrous with sturdy, minute antrorse hairs. Panicle spreading at maturity, $15-25 \mathrm{~cm}$ long, 3-6 cm wide (excluding awns), exserted but the base usually concealed; axis terete, pubescent to scaberulous; branches up to $10 \mathrm{~cm}$ long, terete, pubescent to scaberulous; pedicels up to $10 \mathrm{~mm}$ long, terete to flattened distally, pubescent to scaberulous. Spikelets 16-20 $\mathrm{mm}$ long (excluding awn), slightly gaping. Glumes unequal, glabrous or scaberulous on the nerves, the tips occasionally ciliate, firm and opaque, green or straw-coloured at the base, transparent at the tip, usually with a crescentic purple patch in the middle third; lower glume 16-20 mm long, long-acuminate, the lower 50-75\% 3-nerved; upper glume 12-15 $\mathrm{mm}$ long, acuminate, often broad in the middle, 5-nerved in the lower $50 \%$ the next $20 \%$ 3-nerved. Floret turbinate to cylindrical, $7.0-8.2 \mathrm{~mm}$ long (including callus). Lemma brown at maturity, the surface smooth with long white to slightly fulvous hairs, sparse to absent just below the apex centrally; lobes 2, obtuse, 0.2-0.5 mm long; coma of hairs 2.5-3.5 mm long. Callus 2.0-2.8 mm long, straight, with hairs slightly darker than those of the lemma. Awn 0.3-0.35 mm wide near the base, 5.5-6.5 cm long, weakly twice bent; column $20-25 \mathrm{~mm}$ long, $11-13 \mathrm{~mm}$ to the first bend, pubescent with hairs $0.2-0.3 \mathrm{~mm}$ long; bristle scaberulous or pubescent with hairs 0.2-0.3 mm long. Palea obtuse, slightly shorter than the lemma, ciliate at the tip, pubescent with long hairs between the nerves, the margins glabrous. Lodicules 3, membranous; 2 abaxial $1.5-2.0 \mathrm{~mm}$ long, oblong to slightly spathulate; paleal $0.5-1.0$ $\mathrm{mm}$ long, acute. Anthers 1.2-4.0 mm long, penicillate. Caryopsis 3.5-4.5 mm long; embryo $30-40 \%$ the length; hilum $75-85 \%$ the length.

Specimens Examined: New South Wales: South Western Plains: Kyalite State Forest, Everett 58, $59 \&$ Jacobs, 22.11.1980 (NSW); Kyalite State Forest, Everett 341 \& Jacobs, 16.10 .1981 (NSW); 3 miles [5 km] W. of Stoney Crossing, Henderson NSW 149126, 9.10.1947; c. 3 miles [5 km] W. of Stoney Crossing, Henderson 437 \& 438, 9.10.1947 (NSW); N. of Swan Hill, Henderson 440, 5.11.1947 (NSW); Cunninyeuk, Henderson BB, NSW 149127, 182 CC, 183 DD, 12.10.1946 (NSW); Cunninyeuk, Henderson D, NSW $149128,3.10 .1946$ (NSW).

Named after D.W.L. Henderson, an early surveyor (Latin: metator, genitive metatoris) of western New South Wales, who made many valuable collections of Stipa specimens.

Differs from $S$. eremophila in the longer coma (less than $1 \mathrm{~mm}$ in $S$. eremophila), in the longer and paler hairs of the lemma and in the generally shorter and finer awn relative to lemma size. 


\section{ACKNOWLEDGEMENTS}

This work would not have been possible without financial assistance from the Australian Biological Resources Study which we gratefully acknowledge. We would like to thank Karen Wilson for providing the Latin diagnoses.

\section{REFERENCES}

Burr, E.J. (1968). Cluster sorting with mixed character types. I. Standardization of character values. Austral. Comput. J. 1(2): 97-99.

Jacobs, S.W.L. and Pickard, J. (1981). Plants of New South Wales. A census of the cycads, conifers and angiosperms. (Government Printer: Sydney.)

Lance, G.N. and Williams, W.T. (1967). A general theory of classificatory sorting strategies. I. Hierarchical systems. Comput. J. 9: 373-380.

Lance, G.N. and Williams, W.T., (1977). Attribute contributions to a classification. Austral. Comput. J. 9 (3): 128-129.

Sprengel, K. (1827). Systema vegetabilium. (Dietrich: Göttingen.) Vol. 4; Curae posteriores, p. 31

Townrow, J.E.S., (1978). The genus Stipa L. in Tasmania. Part 3 - Revised taxonomy. Pap. \& Proc. Roy. Soc. Tasmania 112: 227-287.

Vickery, J.W., (1951). Contributions to the taxonomy of Australian grasses. Contr. New South Wales Natl. Herb. 1(6): 322-345. 